\title{
CORPORATE SOCIAL \\ RESPONSIBILITY IN \\ INTERNATIONAL \\ DEVELOPMENT: AN OVERVIEW \\ AND CRITIQUE ${ }^{1}$
}

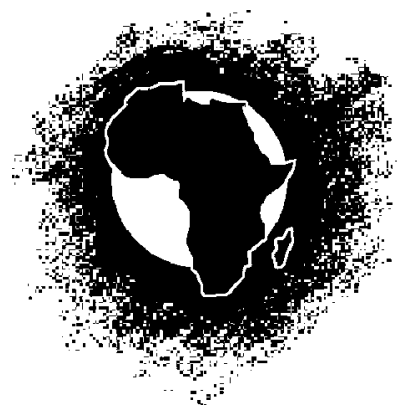

Bryane Michael*

\section{Linacre College, Oxford University, UK}

Within the literature focusing on CSR's role in development, three 'schools of practice' appear to be emerging: the neoliberal school (focused on self-regulation by industry according to the risks and rewards of CSR activity), the state-led school (focused on national and international regulation and co-operation) and the 'third way' school (focused on the role of for profit and not-for-profit organizations. Yet, each of these schools of practice may be critiqued using theories applicable to the broader field of development. Namely, the neo-liberal school fails to address the resource misallocations caused by CSR. The stateled school fails to address the underlying politics behind government encouraged CSR. The 'third way' school fails to address the self-interest involved in CSR. Copyright @ 2003 John Wiley \& Sons, Ltd and ERP Environment.

* Correspondence to: B. Michael, Linacre College, St Cross Road, Oxford OX1 3JA, UK. E-mail: bryane.michael@linacre.ox.ac.uk

${ }^{1}$ Much of the inspiration for this paper comes from the World Bank's America's Conference on Corporate Social Responsibility (World Bank, 2002).

Copyright $@ 2003$ John Wiley \& Sons, Ltd and ERP Environment.
Received 24 January 2003

Accepted 27 May 2003

I n the 1990s and early 2000s, the discourse about 'corporate social responsibility' (CSR) became increasingly prominent within company, government and civil society writing. While there are many definitions of CSR, Holmes and Watts (2000) of the World Business Council for Sustainable Development provide a reasonably representative definition as the 'continuing commitment by business to behave ethically and contribute to economic development while improving the quality of life of the workforce and their families as well as of the local community and society at large'. ${ }^{2}$ Lying behind this definition is the belief that the firm's main objective as defined in the field of corporate finance - maximizing shareholder value - is not sustainable because it ignores a wide range of other actors (or 'stakeholders' such as creditors, customers, debtors, environmental interests and future generations).

\footnotetext{
${ }^{2}$ A survey based attempt at defining CSR made by Corrado and Hines (2001) in Great Britain shows that responsibility to customers was the most important element of CSR (at 20\%) and then responsibility toward the local community (17\%).
} 
Rather than maximize shareholder value, corporations are admonished to take broader social objectives into account. ${ }^{3}$ Given the social and developmental aspects of CSR, by the late 1990s and early 2000s the CSR discourse had disseminated into the international development literature (Natufe, 2001; Walker, 1998). International development organizations such as the World Bank (2002a) were claiming that CSR represents a new vehicle for community economic development, education, disaster relief, environmental protection, health promotion and a wide range of other activities that used to be within the ambit of governments. Yet, as the above definition and the very broad range of subjects treated show, the concept of CSR remains vague.

Despite the ambit and vagueness of CSR, within the literature focusing on CSR's role in development, three 'schools of practice' appear to be emerging: the neo-liberal school (focused on self-regulation by industry according to the risks and rewards of CSR activity), the state-led school (focused on national and international regulation and co-operation) and the third way' school (focused on the role of profit and non-profit organizations). Yet, each of these schools of practice may be critiqued using arguments from the long-running socialism versus capitalism debate and by using theories applicable to the broader field of development. The neo-liberal school fails to address the resource misallocations caused by CSR. The state-led school fails to address the underlying politics behind government-encouraged CSR. The 'third way' school fails to address the selfinterest involved in promoting CSR. CSR (to some extent) represents a business fad - like reengineering of the 1990s - which benefits the parties most vociferously advocating CSR. However - unlike other business fads - it encroaches into the field of social policy.

\footnotetext{
${ }^{3}$ At the time of writing, such admonishments had been greatly increased due to a number of scandals involving corporate malfeasance occurring in the US and Europe.
}

\section{AN OVERVIEW OF CSR THEORIES}

Within the discussion about CSR, there are broadly speaking - three schools of practice: neo-liberal, state-centred and 'third sector' schools of thought. ${ }^{4}$ The neo-liberal school stresses the role of market incentives in encouraging corporate responsibility by company responsiveness to customer preferences for responsible behaviour in product and input allocation decisions. The state-centred school denies the role of the 'invisible hand' as providing for the optimal amount of social attention by firms and argues for active state intervention. The 'third sector' school stresses the important role of NGOs and public-private partnerships in ensuring that social objectives are addressed better than actions undertaken by a dysfunctional state and greedy firms alone.

\section{Neo-liberal school: role of incentives and insurance}

Neo-liberal advocates of CSR operate on the assumption that the adoption of CSR policies by business is rational and profitable in the long run (if not in the short run) because these policies attract product demand and factors of production such as labour and capital. The decision to engage in CSR is different from philanthropy because the corporate sector benefits from investing in long-term sustainable community development (their source of product demand as well as labour and capital supply) rather than simply reaping the simple tax advantages of philanthropic donations. In a simplified version of this view, in all markets, the firm is inspired by both incentives and insurance. ${ }^{5}$ Corporate managers walk a thin

\footnotetext{
${ }^{4}$ This taxonomy was roughly taken from Woods (1988) in his discussion on globalization and the new thematic cross-cutting of relations between government, business and the 'third sector'.

${ }^{5}$ According to the simplest principal-agent conception of the firm (Gibbons, 1998), managers are fundamentally inspired by incentives and insurance (or risks and returns). Grayson et al. (2001) offer a translation of this view in the CSR context.
} 
line between seeking returns from positive consumer, employee and investor perceptions of the company while avoiding the risks of negative government intervention, adverse media exposure, stock market declines and customer boycotts - as the Nike case illustrates (Schwartz and Gibb, 1999; Klein, 2000). ${ }^{6}$ Advocates of the neo-liberal model (such as the World Bank) cite company programmes such as those of Daimler-Chrysler, Du Pont, Shell and DHL. Neo-liberal advocates also cite programmes such as triple-bottom-line initiatives (Elkington, 1997), stakeholder boards (Leam, 2002) and voluntary compliance with codes such as the Caux Principles, the Global Sullivan Principles and the Keidanren Charter. ${ }^{7}$

With regard to product demand, CSR can be seen as one element in a larger branding strategy. By engaging in CSR programmes, marketing them and auditing them, CSR can attract demand from market segments particularly interested in social issues. For example, a MORI poll (2000) showed that 58\% of Europeans agreed that industry and commerce do not pay enough attention to their responsibilities'. One method for such a branding strategy is product certification. Examples of such 'certificates' include the Global Reporting Initiative (GRI) guidelines, the Social Accountability 8000 (SA 8000) standard and the AccountAbility 1000 standard. By signalling that companies are 'socially responsible', this is seen to provide an easily recognizable and universally comparable method of 'selling' corporate responsibility. Moreover, advocates claim a type of herding behaviour could ensue because companies that derive competitive advantage from such certification would see competitors quickly following suit. ${ }^{8}$ Yet, given the relatively low degree of awareness raising by companies, these supposed benefits are suspect. CSR

\footnotetext{
${ }^{6}$ Government is also a stakeholder that must be 'managed' by business (Steiner and Steiner, 2000).

${ }^{7}$ Some commentators include CSR in the wider discussion about corporate governance (Baukol, 2002).

${ }^{8}$ Such effects are known in the industrial organization literature as network effects (Tirole, 1989).
}

may figure among a panoply of other corporate decisions such as service quality, human capital development, stakeholder relations and others, but CSR is - and probably will remain to be - a minor corporate strategic issue.

The role of CSR as a market signal can also be seen in labour markets as well as in product markets. On the labour demand side, companies post their values on the employment web pages to encourage self-sorting of ethical employees. On the labour supply side, CSR signalling is seen both to influence the decision to join the company and to affect human resource policies of employees once inside the company. A number of corporations include descriptions of their corporate responsibility to attract labour - such as AES Corporation (Energy) or, more prominently, the Body Shop. ${ }^{9}$ Once in the company, human resource management decisions become important in the effectiveness of a CSR programme. Three issues relate to organizational structure, training and motivation. Organizational structure is important because, as Murray (2002) notes, many companies have decided to create executive CSR posts - elevating CSR to a corporate function, much like accounting or marketing. And just as any other corporate function, these posts must draw talent and reassign human resources toward monitoring to ensure compliance with ethical standards - the Gap being one example. Yet, these human resource decisions require training - which also is supplied and demanded along market principles. Management plays an important role in promoting the programme and creating incentives for the programme through motivation and example. ${ }^{10}$ Such human resource policies have been contested on the grounds that CSR should not be treated separately and independently

\footnotetext{
${ }^{9}$ Maister (1997), looking at service-firm labour markets in a nonCSR context, notes that a firm's reputation and image are often key factors in labour's decision to seek employment with that company.

${ }^{10}$ In this way, local short-term market principles cannot completely drive the CSR programme as one key argument for the existence of the firm is to correct for market failures (Williamson, 1985).
} 
from other corporate decisions - but should be integrated or 'mainstreamed' into them.

Given the corporate finance maxim that the role of corporate managers is to maximize shareholder value, CSR assumes a large role in capital markets (particular equity markets). Some empirical evidence suggests that CSR and specifically another ambiguous label, 'socially responsible investing' - is important in attracting capital and promoting shareholder value in financial markets. Given the importance of socially responsible investment, several indices - such as the Dow-Jones Sustainability Group Index and the FTSE4Good UK Fund - have been established to measure responsible investment performance. According to the Social Investment Forum (2001) report, approximately $12 \%$ of funds under professional management in the United States fall under the rubric of 'socially responsible investment'. According to Dowell et al. (2000), the adoption of environmental standards appears to increase firms' market values while Baue (2002) notes that social investment vehicles have the potential to outperform the market for example the Domini Social Index's 10-year return has outperformed the S\&P 500. ${ }^{11}$ One explanation for these trends is that social investment may be seen as a 'signalling device' for long-term investors who are unable to accurately monitor managerial talent and executive preferences toward long-term performance. Yet, this evidence can be criticized because socially responsible funds do not always outperform the market and socially responsible investment funds are very different in nature and investment criteria from other investment vehicles. Indeed, some commentators such as McWilliams and Siegel (2000) find some degree of misrepresentativeness in correlations between CSR and financial performance.

\footnotetext{
${ }^{11}$ According to Baue, 'over the ten-year span (again on an annualized basis), the DSI increased 13.27 percent, the fund gained 11.91 percent, with the S\&P 500 falling in between, up 12.63 percent'. Other examples of socially responsible funds include Calvert Social Index Fund (ticker symbol CSXAX), Vanguard Calvert Social Index Fund (VCSIX), Walden B\&BT Domestic Social Index Fund (WDSIX) and the MMA Praxis Value Index Fund.
}

State-centred school: role of co-operation and regulation

Advocates of state-centred (or state-led) CSR believe that national and international policy makers should actively promote the creation and enforcement of CSR obligations on companies. National policymakers should intervene for a number of reasons - mostly related to the potential public goods nature of CSR work (National Policy Association, 2002; Commission of the European Communities, 2002). First, CSR creates positive externalities - in terms of higher consumer welfare, environmental protection and employee satisfaction that individual companies may not be able to appropriate or internalize in their investment decisions. Two rather graphic representations of this argument are the advocacy of 'planetary bargain' between the public and private sectors (Hopkins, 1998) and the needs for 'corporate citizenship' or that corporations like individuals have rights and obligations vis-àvis the polity (McIntosh et al., 1998; Henderson, 2001). Second, government should initiate the process of corporate responsibility in an industrial setting as part of its regulatory and tax framework - given the first-mover type problems (in the form of higher operating costs for individual companies). Rather than certification as a branding strategy as mentioned above, CSR compliance serves as a method of solving 'collective action problems'. Marketenhancing solutions to these externalities are proposed - such as tax incentives, subsidization of CSR programmes, environmental, labour and product standards, competition policy, community reinvestment and other regulation (Positive Outcomes, 2001). Third, government is often required to facilitate rather than regulate. Examples of such facilitation include 'talking up' CSR, establishing rewards for CSR programmes and establishing highlevel CSR government posts - such as in the UK (Positive Outcomes, 2001). ${ }^{12}$

\footnotetext{
${ }^{12}$ The UK is one of the most progressive governments in pushing for CSR (UK Department of Trade and Industry, 2001).
} 
International policymakers - in agencies such as the World Bank, UN, OECD and EU have also been playing a greater role in promoting state-led CSR. A large part of this work has been justified on the grounds that CSR conducted through such bodies would solve first-mover problems on the international scale as companies within a country could claim that even if the playing field were level nationally, it would be unequal internationally. The World Bank has conducted a number of workshops and seminars and is increasing trying to become a centre for CSR theory (World Bank, 2002). The United Nations and OECD also have CSR 'products' - namely the UN's Global Compact (1999) and the OECD Guidelines for Multinational Enterprises (2000). The European Union has done the most notable work on CSR at the international level. The Commission of the European Communities (2002) has recently released a green paper outlining a number of recommendations about a European CSR action framework, improving knowledge about CSR, facilitating the exchange of 'good practice', developing CSR management skills, standards and measurements, fostering CSR among SMEs, promoting convergence and transparency of CSR practices and tools, launching an EU 'multistakeholder forum' on CSR and integrating CSR into EU policies related to employment and social affairs, enterprise policy, environmental policy, consumer policy, public procurement policy, external relations policies and public administration.

However, there are a number of reasons to be circumspect about state-led CSR. First, the facilitation approach is seen as best because of the standard argument of 'government failure' with all the problems of over-bureaucratization, politicization, 'regulatory capture' and inefficiency described for other areas of government intervention (Datta-Chauduri, 1990). Second, governments tend to act as agents of their national corporations in the international arena and hence in a world of rich and poor nations there is very little governmental pressure on corporations to act in a socially responsible manner. Third, given the fact that most government work to date has been focused on guidelines and recommendations, there is a concern that government action is simply a muddling through strategy in support of business interests.

The third sector: the role of non-profit and for-profit NGOs

Rather than company-led or government-led initiatives, many commentators see the third sector (NGOs and civil society broadly defined) as the motor of CSR. ${ }^{13}$ Given the overall rise in the importance of the third sector, in general, their representation in the CSR discourse is reflexive of this overall trend. There are commonalities between these organizations. First, in some sense, they 'represent civil society'. Namely, they seek to influence policymaking without being part of the government or strongly attached to the industrial business sector. Second, they fulfil an educational role - informing consumers, business and policymakers. Third, they often work in collaboration with government and/or business. These organizations may be divided into non-profit NGOs, and for-profit NGOs. ${ }^{14}$ However, there are several problems with this taxonomy. First, the official organizational form may be ostensibly place the organization in a different classificatory category than one that represents the main income stream of the organization. For example, Social Accountability International (SAI) defines itself as a 'charitable human rights organization' despite having significant income streams from corporate members and other sources. Second, partnerships in the third sector may cross orga-

\footnotetext{
${ }^{13}$ For more on the third sector, see Anheier and Seibels (1990). The organizations reviewed were sampled from the International Business Leaders Forum website on 'key players' and do not include all the topic areas covered by the World Bank - particularly CSR NGOs engaged in environmental protection and health promotion. ${ }^{14}$ See Bebbington (1993) or Vakil (1997) for a fuller taxonomy of NGOs.
} 
nizational types; a non-profit NGO may partner with a profit making NGO for part of a project's proceeds - as the co-operation of CSR Europe, The Copenhagen Centre and other business and academic representatives to launch the European Academy of Business in Society shows. Third, even the official classification of NGO may be blurry - as an NGO may have sufficient close financial or personnel links with business or government to merit uncertainty about its true organizational form - such as the government-established Copenhagen Center.

Non-profit NGOs serve either the interests of their members and their staffs or those of a larger community. These tend to engage CSR as one activity among a portfolio of activities. These are also focused more toward non-business interests - such as human rights - than their relatively tightly niched for profit counterparts. Moreover, they tend to have memberships for sale and while claiming they are non-profit still raise a significant amount of revenue for staff salaries and organizational expansion. They also appear by size and number to be a large component of the overall CSR 'third sector'. This survey found three types of organization working on CSR: company membership organizations, human rights groups and educational establishments.

Three examples of company membership CSR organizations include the Copenhagen Centre, BSR and the WBCSD. The Copenhagen Centre is an 'international, autonomous institution established by the Danish Government' making it one of the only NGOs surveyed to be established by a government. ${ }^{15}$ A number of Danish and European policymakers and large business representatives sit on its Board of Directors and Advisory Forum. Rather than directly engaging in CSR work at the firm level, it appears to provide 'public goods' to

\footnotetext{
${ }^{15}$ This information and all other information about the Copenhagen Center was found at http://www.copenhagencentre.org/
}

Copyright (C) 2003 John Wiley \& Sons, Ltd and ERP Environment 'conduct surveys, organize and facilitate networks, establish an interactive knowledge centre, publish reports, notes and newsletters, organise and facilitate international seminars and to support international networking'. ${ }^{16}$ Business for Social Responsibility (BSR) is a global non-profit membership-oriented organization, which offers advisory services and organizes conferences. BSR publications tend to focus on a wide range of issues from business ethics, environment and human rights. ${ }^{17}$ Some of their members include AT\&T, CocaCola, J.P. Morgan and Starbucks. The World Business Council for Sustainable Development (WBCSD) is a membership-based organization of 160 international companies united by a shared commitment to sustainable development via economic growth, ecological balance and social progress. ${ }^{18}$ Their members are drawn from more than 30 countries and 20 major industrial sectors. They work on a number of areas and recent work includes such diverse projects as a study on technology transfer to developing countries and the role of governments, businesses and NGOs in 'building a low carbon future'.

There are two organizations that place CSR within a larger human rights movement: Civicus and Social Accountability International (SAI). The large NGO Civicus addresses CSR broadly, engaging in programmes focus on promoting the involvement of women, youth and corporate philanthropy and corporate citizenship and developing a global citizen commitment. ${ }^{19}$ It is financed mainly by donors such as the Carnegie Corporation, Ford Foundation, DFID and CIDA. Social Accountability International (SAI) is focused more directly on CSR by developing the 'Social Accountability 8000 (SA8000)' standard for workplace condi-

\footnotetext{
${ }^{16}$ The Copenhagen Center does not officially define itself as a membership organization. Yet, its Board of Directors and Advisory Forum appear to fulfil the same function of lending support to the operations of the Center.

${ }^{17}$ Information is available at

http://www.bsr.org/Meta/About/index.cfm

${ }^{18}$ Information available at http:/ / www.wbcsd.ch/

${ }^{19}$ Information available at http://www.civicus.org/
} 
tions and a system for independently verifying factories' compliance, and gives 'corporate conscience awards' ${ }^{20}$ They have an advisory board and declare themselves to be a 'charitable human rights organization'. However, there is little information available on the Internet about their organization.

A third type of non-profit NGO working on CSR is educational establishments. Schools are in principle independent from either business or government interests and serve educational objectives rather than simply profit-based ones. ${ }^{21}$ As a school of practice, in their ideal type, they are 'constrained' by the liberal mandate to cast a critical reflection upon CSR and to conceptualize issues rather than focus on day-to-day practical matters that other third sector organizations may address. ${ }^{22}$ The International Business Leaders Forum is 'an international educational charity set up in 1990 to promote responsible business practices internationally that benefit business and society'. ${ }^{23}$ However, as with other NGOs, 'The Forum is supported by financial contributions from, and the leadership demonstrated by, 60 major global companies from Europe, America, Asia and the Middle East' - calling their independence into question. Boston College's Center for Corporate Community Relations hosts a Resource Center on Corporate Citizenship including material about community relations and CSR from more than 1000 corporations and information on more than 400 noncorporate organizations. ${ }^{24}$ However, their independence is also questionable, given that they appear to be a membership-based organization offering a number of products including

\footnotetext{
${ }^{20}$ Information available at http:/ / www.sa-intl.org/

${ }^{21}$ Given the fees obtained by some of these programmes, and the method of operation, in practice, many of these programmes may be more similar to non-profit or for-profit NGOs.

${ }^{22}$ For a study of how leading US business schools incorporate corporate involvement in community economic development in their curricula see Wood et al. (2002).

${ }^{23}$ Information available at

http:/ / www.iblf.org/csr/csrwebassist.nsf/content/e1.html

${ }^{24}$ Information available at

http://infoeagle.bc.edu/bc_org/avp/csom/cccr/info.html
}

'executive education', 'convenings' and 'consulting services'.

For-profit NGOs serve principally the interests of the management and the stakeholders of the NGO. By focusing on profitable market segments and developing 'products' aimed at these segments, these organizations tend to have well-niched and specialized services aimed at selling publications, organizing expensive conferences and offering consulting services. Examples include CERES, CCC, CSR Europe, SustainAbility and MHC. The Coalition for Environmentally Responsible Economies (CERES) created the Global Reporting Initiative (GRI) 'to standardize corporate sustainability reporting worldwide'. ${ }^{25}$ They are an 83-member 'coalition membership' with 15 staff members and there is no mention on their webpage about their sources of finance. The Corporate Citizenship Company offers consultancy services to help corporations manage their global social responsibility and community involvement activities'. They do not have the complex membership structures that the non-profits have and their clients have included Ford India, Vodafone, Unilever, South African Breweries and Guinness UDV. CSR Europe is a membershipbased organization. ${ }^{26}$ They do not appear to solicit members as the others do. Their programmes cover a wide range of issues including business and diversity, finance, employee involvement, cause-related marketing, communication and measurement of CSR and others. SustainAbility is a 'for-profit limited company' with about 140 clients listed on the webpage. Specifically, it is an independent management consultancy and think-tank dedicated to promoting the business case for sustainable development. ${ }^{27} \mathrm{MHC}$ International (looking specifically at international development issues) seems to focus on publications and advising services.

\footnotetext{
${ }^{25}$ Information available at http:/ / www.ceres.org/

${ }^{26}$ Information available at http:/ / www.csreurope.org/

${ }^{27}$ Information available at http:/ / www.sustainability.co.uk/
} 


\section{CSR IN THE WIDER DEVELOPMENTAL CONTEXT}

It would seem, as Henderson (2002) states, that 'today's conception of Corporate Social Responsibility (CSR) marks a new departure'. Yet, each of these schools of practice places itself squarely into long-running debates about the virtues and vices of the socialist versus capitalist system. Heilbroner (2002) discusses the flaws of socialism with its emphasis on the politicization of firms to achieve social objectives. On economic grounds, 'social production' was claimed to lead to misallocation of resources within the firm and the broader economy. On political grounds, social production was seen to 'politicize production', thereby removing legitimate political activity from the political sphere. On social grounds, 'social production' was a method of reducing civil society influence by assigning social issues to industry. Instead, CSR represents a small part of a broader change in the relations between government, business and civil society - and is symptomatic of the search for new organizational forms related to these changing relations. ${ }^{28}$

\section{Economic consequences}

The neoliberal argument of using risks and incentives to drive the CSR agenda seems ostensibly plausible. However, what appears as market-led non-intervention of the invisible hand can often be ideologically based intervention of the visible managerial hand. CSR can cause resource misallocation and diversion within the firm and distortion of incentives within the economy. Resource misallocation within the firm includes the diversion of managerial time and resources through the creation of CSR executive posts and staff time dedicated to activities that are essentially in the marketing function (Murray, 2002). If CSR were based

\footnotetext{
${ }^{28}$ Many of these changes are addressed in the globalization literature - see Held et al. (1999).
}

on market signals, then CSR activity would focus on coherently analysing community needs along rational lines using methods such as 'social marketing' (Kotler, 1989). However, much CSR activity instead appears politically motivated, based on pre-existing relationships or the public relations (PR) needs for the firm. Moreover, even assuming that social needs could be adequately identified and priorities established, many CSR initiatives involve significant 'transaction costs', as many of the proposed guidelines entail relatively large costs in time and money to prepare, interpret and use them.

Second, and directly related to the above point, the economics governing social planning (and the experience of the socialist economies is instructive) have not disappeared. By not relying on market signals, CSR could distort resource allocations at the microeconomic level, leading to distorted prices, input decisions and production decisions. In theory, one of the reasons why markets are efficient is because they allow the most valued goods and services to flow to those that want them the most. Reyes (2002) for example describes the partnership of the Philippine national fast-food chain Jollibee with the Kabisig ng Kalahi (a private group) and the Department of Social Welfare and Development to provide food to poor people. She notes that 'Kabisig chooses the organizers, treasurers and cooks who will plan the budget and do the necessary chores ensuring that their kids are fed'. Yet, such activity determines the distribution of food based on participation, social networks and objectives defined by NGO (and ultimately business) interests. Another example of the mixing of corporate and social objectives comes from Citibank's financial services education programme, which 'will provide sixth-form students in four schools with a grounding in "all facets of the financial services industry". This is, in the words of the governor, a wonderful example of Citigroup manifesting its corporate and social responsibility' (Management Today, 2002). In the Jollibee 
example, there is little evidence to suggest that resources were targeted at groups who were in the greatest need or that the food provided catered to their nutritional needs (Jollibee is a fast-food chain). In the Citibank case, the programme may well have been misallocating resources, which might have been better spent on basic reading, writing and arithmetic. In both cases, at the most cynical interpretation, these programmes could try to create market demand, 'capture' future markets, impose 'switching costs' and attempt to rectify the bad publicity of branding in the 1990s (Klein, 2000).

A third type of misallocation occurs in the direction of resources toward enterprises that engage in CSR training and conferences. To the extent that these activities substitute at the margin for other programmes such as direct donations to NGOs specialized in a particular type of public service provision, then they are inefficient. Moreover, because CSR investments are piece-meal and usually undertaken by firms with stocks of discretionary capital, there is no guarantee that resources will be best placed between sectors and geographic regions. If capital is given to CSR firms, then such capital flows may be rewarding a particular type of marketing rather than the efficient production of goods and services demanded by the market. In other words, the rents accruing to these companies could be based on marketing values due to the temporary stimulation of demand for this type of activity rather than the value arising from the production of more permanent and important needs. If these investments are 'strategic' (in the sense that they are designed to give a company competitive advantage based on these marketing values), then there is no guarantee that there will be over-investment in these sectors and under-investment in less PR-intensive sectors.

Fourth, even though CSR programmes might appear to solve collective action problems related to CSR-related first-mover and public goods problems mentioned previously, action on CSR itself appears to suffer from a 'tragedy of the commons' type collective action problem. For example, the IBLF lists 20 organizations responsible for CSR and a simple Internet search reveals many more. The existence of such a large number of organizations as well as possible competition between them suggests the possibility of destructive competition, which consolidation in a public sector might resolve. A fifth and last type of misallocation may occur due to the politicization of the organization. The 'stakeholder model' politicizes the organization at two levels. At the governance level, 'stakeholder' boards may introduce a range of politically appointed or 'token' representatives. At the operational level, to the extent that guidelines such as the GRI appear to politicize the organization, they may create directly unproductive activity or generate tournaments rather than promote responsibility. The CSR function, just like any other bureaucratic entity, is another 'lobby' for budgetary resources and senior managerial attention - a lesson that many over-sized governments and conglomerate corporations learned in the US in the 1970s.

\section{Political consequences}

The state-led school seems to herald an era of government co-operation in private sector development and progressive regulation aimed at creating a better kind of capitalism. Underneath this rhetoric though lie conflictual forces, which still pit government against business and vice versa. First, rather than simply representing an area of possible regulation, CSR represents a site of contestation for the right to determine social objectives and the funding of these objectives. CSR offers policymaking powers to businesses because it allows them to determine the CSR agenda. To the extent that companies determine social policy over democratically elected and monitored governments, this represents a democratic deficit and lack of accountability. While a certain amount of 'stakeholder' participation may be beneficial, the involvement of business in policymaking in the CSR context reflects 
wider trends of changing power between business and government - resulting in some cases either the 'capture' or 'retreat' of the state (Monbiot, 2000; Strange, 1997). The effort of the EU to shape the CSR agenda is suggestive of the political nature of CSR. If the EU becomes the dominant body determining CSR regulation, this would imply a shift of such regulatory power away from both national governments and business toward this international body. Perhaps the fact that the EU is trying so hard to promote CSR reporting standards suggests the nature of this political contest (taking power from business and from nation states).

Second, as the EU example shows, CSR also represents a site of political contestation at the international level. At the most optimistic, the increasing elaboration of policies (including CSR at the international level) represents a type of multi-layered government where power shifts to international organizations and multi-national corporations - adding another layer of governance (Held et al., 1999). At the most pessimistic, such activity represents a type of 'mandate creep' (Einhorn, 2001). By appropriating CSR agenda-setting, these institutions arrogate the relatively non-transparent and non-accountable moral and even legal rights to regulate business and government relations at the international level. An example of an international initiative impacting CSR is the OECD's Guidelines for Multinational Enterprises. OECD governments (and particularly the United States) endorse CSR in one form or another, and many of the 'best practices' come from US firms. Yet, by adopting international guidelines, countries cede their right to determine their own corporate practices. Moreover, the choice of the OECD as the forum for such suggests a strong regulatory aspect. Guidelines do not have the same legal force as OECD conventions; however, they are still strongly recommended to OECD governments. A less legalistic forum is the United Nations and its Global Compact. Both instruments are often cited as international action in the realm of
CSR. Yet, neither the Guidelines nor the Compact directly mention the term 'corporate social responsibility'. Presumably, increased association of these projects with CSR is the first step toward legitimacy that the OECD and UN secretariats need for the direct inclusion of CSR text in these document.

Third, at an ideological level, CSR represents a way of moving toward 'market socialism' (Arnold, 1994) and the 'third way' (Giddens, 1998) between free markets and socialist concern for social rights. Indeed, social theorists as far back as Adam Smith and Karl Marx have written widely on the need for firms to take social objectives into account Smith (1759) in his discussion about the 'impartial spectator' and Marx (1848) in his advocacy of the socialist revolution. There have also been many previous attempts to integrate social issues into firms - such as German type 'co-determination' boards. However, rather than being discussed at the political level, CSR is taken as a company technocratic exercise - thus 'depoliticizing' the decision to include social objectives in business. In other words, CSR - which is a fundamentally political issues - is given the appearance of a 'technical issue' by the governments, firms and NGOs advocating it in order to allow 'experts' (namely those persons advocating CSR programmes) sole domain over decisions taken about CSR. ${ }^{29}$

\section{Social consequences}

The third-sector school appears to signal a new type of co-operation between business and government - intermediated by representatives of civil society. However, just as CSR is a site of political contestation, it is a site of social contestation. First, much of the literature treats CSR as a technical exercise, which NGOs - whether for profit or not - can engage in

\footnotetext{
${ }^{29}$ CSR's treatment of a highly political subject as a technical exercise also reflects a much broader trend in the 'depoliticization' of policymaking (Escobar, 1995; Hobart, 1993; Ferguson, 1990).
} 
based on their expert knowledge - reflecting the same type of 'depoliticization' mentioned above but benefiting NGOs rather than firms. Second, in some ways, CSR represents a 'new social movement'. Following on the work of Hanspeter et al. (1995) or Sklair (1995) is the observation that, since the 1960s, the struggle between capital and labour (if these classes could ever be defined) has taken on new forms of confrontation. Through a number of social issues such as environment or women's rights, people express their political preferences. Underneath the CSR discourse lie many tensions between managers, workers, government, consumers and social activists. Corporate social responsibility can be seen in this light as the rejection of the exercise of power by corporate managers to the detriment of other stakeholders such as consumers or environmental interests. CSR also rejects the exercise of government power in regulating business as well as the exercise of 'worker' power - many of whom are less responsible than their bosses. ${ }^{30}$ Foweraker (1995) positions the argument more generally, noting that such social movements represent a type of identity politics which again extends beyond the concept of worker to individual subjectivities such as 'consumer' or 'social activist'.

From a developmental context, social movements may be classified into in three broad schools: new social movements, resource mobilization theory and political process approach (Foweraker, 1995). While there are many theories about new social movements, new social movements represent the response to increasing political bureaucratization, market commodification and cultural massification (Slater, 1985). CSR qualifies on each of these fields: representing a broader wave in reducing the role of the state while simultaneous rejecting corporate power and focus on each company's specificities. Resource mobi-

\footnotetext{
${ }^{30}$ The organizational density of CSR had led to the diffusion of CSR activity. For a general discussion of this effect, see Minkoff (1997).
}

Copyright @ 2003 John Wiley \& Sons, Ltd and ERP Environment lization theory would see CSR from the viewpoint of competition and co-ordination between the profit and non-profit organizations mentioned above. For profit NGOs, CSR is simply a profit maximizing activity - representing one activity in a larger portfolio of grant generating activities. Rich groups set the agenda as most meetings are too expensive or the jargon employed too specialized for workers and SMEs. The political process approach would see CSR as simply a form of machine politics. Declarations by the Bush administration in the US clearly indicate that CSR is also a political issue.

CSR-focused NGOs reflect the same problems as other types of NGO. There are a number of problems that affect NGOs, including expectations of NGO performance being unrealistically high and excluding other options for development (Stewart, 1997), and foreign NGOs may not reflect domestic interests (Heap, 2000). However, CSR NGOs particularly seem to be affected by two dangers. First, the role of legitimacy in NGOs is questionable as they are not elected and are unaccountable to voters (Atack, 1999). Many of the CSR NGOs surveyed contribute to policymaking, yet are only accountable to their financially contributing donors and members. Second, governments, business and NGOs may 'capture' one another. States may 'capture' NGOs and use them to 'privatize' the making of public policy (Raftopoulos, 2000; Ndegwa, 1996). Twenty years ago, CSR would have been treated by governments, who might establish a Department of Corporate Social Responsibility. Now, governments are spared the fiscal burden of managing CSR programmes by encouraging private parties to engage in CSR activities. Yet, even though ostensibly private, government may capture these NGOs. Given the close links between the government and The Copenhagen Centre, one questions the degree of 'capture' extending from business to government or vice versa. Companies as well as governments may 'capture' NGOs (Bendell, 2000; Mitchell, 1998). 
The significant financial involvement of large corporations in CSR NGOs brings into question the impartiality of these organizations to business interests.

\section{CONCLUSION}

The CSR discourse appears to signal a new form of co-operation between government, business and civil society in the promotion of social objectives. Yet, left out of the discourse are all the difficulties and complexities that development theory has been debating for a century. The neo-liberal school stresses the adequacy of the incentives versus insurance model - yet fails to address important resource misallocations. The state-led school emphasizes the balance between co-operation versus control exercised by the state - yet ignores important contestation of political power by international organizations, national governments and business interests. The 'third-sector' school notes the new potential for public engagement in policymaking - but ignores the highly politicized and conflictual nature of that engagement. CSR is part of a larger transformation in the relations between government, business and civil society. The adoption of social objectives by companies is not as new as the 'corporate social responsibility' label suggests. Instead, it touches the 80-year debate between capitalism and socialism. The vague and all-encompassing CSR discourse serves as a forum for advocating the interests of business, government and relatively nonaccountable NGOs. Governments advocating CSR benefit by both extending regulatory control and devolving actual implementation to business. Business benefits from CSR by increasing regulatory autonomy. NGOs benefit by gaining increased policymaking functions and earning money from both government and business (in the form of grants and donations). Yet, while the actors most loudly advocating CSR may benefit, society as a whole may be harmed.

\section{REFERENCES}

Anheier H, Seibels W (eds). 1990. The Third Sector, Comparative Studies of Non Profit Organizations. de Gruyter: Berlin.

Arnold N. 1994. The Philosophy and Economics of Market Socialism: a Critical Study. Oxford University Press: New York.

Atack I. 1999. Four criteria of development NGO legitimacy. World Development 27: 855-864.

Baue W. 2002. Social index funds mirror their benchmarks. SRI News 15 March.

Baukol R. 2002. Corporate Governance and Social Responsibility, Caux Round Table, Tokyo, 2002.

Bebbington A. 1993. Non-Governmental Organisations and the State in Latin America. Routledge: London.

Bendell J. 2000. Terms for Endearment - Business, NGOs and Sustainable Development. Greenleaf: Sheffield.

Clarson M. A stakeholder framework for analyzing and evaluation corporations. The Academy of Business Review 20(1): 92-117.

Commission of the European Communities. 2002. Corporate Social Responsibility: a Business Contribution to Sustainable Development, COM (2002) 347 final. Brussels.

Corrado M, Hines C. 2001. Business Ethics - Making The World a Better Place.

http://www.mori.com/pubinfo/pdf/business_ethics. pdf [20 September 2002].

Datta-Chauduri M. 1990. Market failure or government failure? Journal of Economic Perspectives 4(3): 25-39.

Department of Trade and Industry. 2001. Developing Corporate Social Responsibility in the UK Business and Society.

Dowell G, Hart S, Yeung B. 2000. Do corporate global environmental standards create or destroy market value. Management Science 46(8): 1059-1074.

Einhorn J. 2001. The World Bank's mission creep. Foreign Affairs September/October.

Elkington J. 1997. Cannibals With Forks - The Triple Bottom Line of the 21st Century Business. New Society: London.

Escobar A. 1995. Encountering Development: the Making and Unmaking of the Third World. Princeton University Press: Princeton, NJ.

Ferguson J. 1990. The Anti-Politics Machine: 'Development', Depoliticisation, and Bureaucratic Power in Lesotho. Cambridge University Press: Cambridge.

Foweraker J. 1995. Theorising Social Movements. Pluto: London.

Gibbons R. 1998. Incentives in organizations. Journal of Economic Perspectives 12(4): 115-132.

Giddens A. 1998. The Third Way: the Renewal of Social Democracy. Polity: Cambridge.

Grayson D, Hodges A, Kindersley D. 2001. Everybody's Business: Managing Risks and Opportunities in Today's Global Society. Financial Times. 
Hanspeter K, Koopmans H, Duyvendak J, Giugni M. 1995. New Social Movements in Western Europe: a Comparative Analysis. University of Minnesota Press: Minneapolis, MN.

Heap S. 2000. NGOs Engaging with Business. INTRAC: Oxford.

Heilbroner R. 2002. Entry on Socialism. Concise Encyclopedia of Economics.

Held D, McGrew A, Goldblatt D and Perraton J. 1999. Global Transformations: Politics, Economics and Culture. Polity: Cambridge.

Henderson D. 2001. Misguided Virtue: False Notions of Corporate Social Responsibility. Institute of Economic Affairs: London.

Hobart M (ed.). 1993. An Anthropological Critique of Development: the Growth of Ignorance. Routledge: London.

Holmes L, Watts R. 2000. Corporate Social Responsibility: Making Good Business Sense. World Business Council for Sustainable Development.

Hopkins M. 1998. The Planetary Bargain: Corporate Social Responsibility Comes of Age. Macmillan: London.

Klein N. 2000. No Logo. HarperCollins: New York.

Kotler P. 1989. Social Marketing: Strategies for Changing Public Behavior. Free Press: New York.

Leam D. 2002. All Aboard: Improving Public Service Accountability. Social Market Foundation: London.

Maister D. 1997. Managing the Professional Service Firm. Free Press: New York.

Management Today. 2002. 10 June.

Marx K. 1848. Communist Manifesto.

McIntosh M, Leipziger D, Jones R, Coleman G. 1998. Corporate Citizenship: Successful Strategies for Responsible Companies. Financial Times Management: London.

McWilliams A, Siegel D. 2000. CSR and financial performance: correlation or misspecification? Strategic Management Journal 21: 603-609.

Minkoff D. 1997. The sequencing of social movements. American Sociological Review 62: 779-799.

Mitchell J. 1998. Companies in a World of Conflict: NGOs, Sanctions and Corporate Responsibility. Royal Institute of International Affairs-Earthscan: London.

Monbiot G. 2000. Captive State: the Corporate Takeover of Britain. Macmillan: London.

MORI. 2000. Corporate Social Responsibility Update. Issue 2.

Murray S. 2002. Inside track. Financial Times 11 June: 17, 849.

National Policy Association. 2002. The Government's Role in CSR and Governmental Activities. http:/ / www.multinationalguidelines.org/csr/government's_role.htm [19 September 2002].

Natufe I. 2001. The problematic of sustainable development and corporate social responsibility: policy impli- cations for the Niger Delta. Presented at the Urhobo Historical Society Second Annual Conference and General Meeting, Denville, NJ, 2001.

Ndegwa S. 1996. The Two Faces of Civil Society: NGOs and Politics in Africa. Kumarian: West Hartford, CT.

OECD. 2000. OECD Guidelines for Multinational Enterprises, ministerial booklet. Paris.

Positive Outcomes. 2001. CSR: the Challenges and Opportunities for Government, presentation.

Raftopoulos B. 2000. The state, NGOs, and democratisation. In NGOs, the State and Politics in Zimbabwe, Moyo S, Makumbe J, Raftopoulos B (eds). Southern Africa Printing and Publication: Harare.

Reyes I. 2002. Business World.

Schwartz P, Gibb B. 1999. When Good Companies Do Bad Things: Responsibility and Risk in an Age of Globalization. Wiley: New York.

Sklair L. 1995. Social Movements and Global Capitalism. Johns Hopkins University Press: Baltimore, MD.

Slater D. 1985. New Social Movements and the State in Latin America. CEDLA: Amsterdam.

Smith A. 1759. The Theory of Moral Sentiments.

Social Investment Forum. 2001.

Steiner G, Steiner J. 2000. Business, Government and Society: a Managerial Perspective: Text and Cases. McGraw-Hill: Boston, MA.

Stewart S. 1997. Happy ever after in marketplace: NGOs/uncivil society. Review of African Political Economy 24(71): 11-34.

Strange S. 1997. The Retreat of the State. Cambridge University Press: Cambridge.

Tirole J. 1989. Network externalities, standardization and compatibility. In The Theory of Industrial Organization, Tirole J (ed.) MIT Press: Cambridge; 404-410.

United Nations. 1999. The Global Compact: the Nine Principles. New York.

Vakil A. 1997. Confronting the classification problem: toward a taxonomy of NGOs. World Development December.

Walker J. 1998. Socially Responsible Business. Department for International Development Social Development Division.

Williamson O. 1985. The Economic Institutions of Capitalism. Free Press: New York.

Wood D, Davenport K, Blockson L, Van Buren H III. 2002. Corporate involvement in community economic development. Business and Society 41(2): 208-241.

Woods N. 1988. Editorial introduction globalisation, definitions debates and implications. Oxford Development Studies 26(10): 8-23.

World Bank. 2002. Corporate Social Responsibility and Sustainable Competitiveness.

http:/ / www.worldbank.org/wbi/corpgov/csr/index .html [20 September 2002]. 


\section{BIOGRAPHY}

Bryane Michael is currently at Oxford studying organizational reform and international development. He has worked for a number of years at the World Bank and the OECD. He may be reached at Linacre College, Oxford, or E-mail: bryane.michael@linacre.ox.ac.uk Full postal address: Bryane Michael, Linacre College, St Cross Road, Oxford OX1 3JA, UK. 